\title{
Penegakan Hukum Atas Keadilan Dalam Pandangan Islam"
}

(FAIR LAW ENFORCEMENT IN THE ISLAMIC VIEW)

\author{
M. Rais Ahmad ${ }^{1}$ \\ Ketua PPM - UIKA Bogor \\ Jl. KH. Sholeh Iskandar Bogor \\ E-mail: rais.ahmad@yahoo.com
}

\begin{abstract}
The human being is a very important factor in achieving legal justice. Legal justice is very coveted by anyone, including offenders though. If in a country that tends to act unjust law, including judges, then the government must act to prevent it. The government should enforce legal justice, not even apply to the unjust people. So that social justice can be created in people's lives, in addition there is help each other in doing good. There is a sense of interdependence with one another in social life (interdependence).
\end{abstract}

Keywords: Islam, Justice, Law Enforcement

\begin{abstract}
Abstrak: Faktor manusia merupakan sesuatu yang sangat penting dalam mencapai keadilan hukum. Keadilan hukum sangat didambakan oleh siapa saja termasuk pelaku kejahatan sekalipun. Jika dalam suatu negara ada yang cenderung bertindak tidak adil secara hukum, termasuk hakim, maka pemerintah harus bertindak mencegahnya. Pemerintah harus menegakkan keadilan hukum, bukan malah berlaku zalim terhadap rakyatnya. Sehingga keadilan sosial dapat tercipta dalam kehidupan masyarakat, selain terdapat saling tolong-menolong sesamanya dalam berbuat kebaikan. Terdapat naluri saling ketergantungan satu dengan yang lain dalam kehidupan sosial (interdependensi).
\end{abstract}

Kata Kunci: Islam, Keadilan, Penegakan Hukum

* Diterima tanggal naskah diterima: 10 Juli 2013, direvisi: 23 Agustus 2013, disetujui untuk terbit: 15 November 2013.

${ }^{1}$ Disampaikan pada Diskusi Ilmiah terbatas, Selasa 9 Maret 2010 
"Seorang raja jatuh sakit dan obatnya hati seorang pemuda. Ditemukan pemuda desa dengan izin orang tuanya jadi tumbal dengan imbalan harta. Ketika dibawa ke istana untuk dieksekusi, raja masih perlu payung hukum dari hakim kerajaan yang dengan mudah memberi keabsahan hukum membunuh pemuda itu untuk diambil hatinya sebagai obat sang raja. Ketika pemuda itu siap dieksekusi mati, raka terkesima melihat pemuda itu menadahkan kedua tangannya ke atas dengan tersenyum penuh kedamaian. Raja bertanya penasaran, kenapa kamu tersenyum padahal telah di ambang kematian? Aku pasrah kepada Tuhanku sambil mengadu. Apa yang kamu adukan

kepada Tuhan, tambah raja. Aku tak bisa pikir kenapa kedua orang tuaku tega menyerahkan aku untuk dibunuh yang seharusnya mereka cintai hanya karena imbalan harta. Aku juga heran kepada hakim, begitu takut kepada raja ketimbang kepada Allah? Aku semakin tak mengerti kenapa raja mau mengorbankan lain yang tak berdosa untuk kesembuhan dirinya." (Haidar Nashir 2010: 1)

Kutipan diatas boleh dikatakan sebagai sinopsis dari pengalaman panjang keberpihakan hukum kepada kekuasaan sepanjang sejarah.

\section{Pendahuluan}

Penegakan hukum dalam konteks law enforcement sering diartikan dengan penggunaan force (kekuatan) dan berujung pada tindakan represif. Dengan demikian penegakan hukum dalam pengertian ini hanya bersangkutan dengan hukum pidana saja. ${ }^{2}$ Dalam tulisan ini dikehendaki pengertian penegakan hukum itu dalam arti luas secara represif, maupun preventif. Konsekuensinya memerlukan kesadaran hukum secara meluas pula baik warga negara, lebih-lebih para penyelenggara negara terutama penegak hukumnya. Adapun penegak hukum meliputi instrumen administratif yaitu pejabat administratif di lingkungan pemerintahan. Sedangkan dalam lingkungan pidana dimonopoli oleh negara melalui alat-alatnya mulai dari kepolisian, kejaksaan dan kehakiman sebagai personifikasi negara.

Penegakan hukum saja tidaklah cukup tanpa tegaknya keadilan. Karena tegaknya keadilan itu diperlukan guna kestabilan hidup bermasyarakat, hidup berbangsa dan bernegara. Tiap sesuatu yang melukai rasa keadilan terhadap sebagian dari masyarakat bisa mengakibatkan

\footnotetext{
2 Jurandi Hamzah, 2005: 48
} 


\section{Rais Ahmad}

rusaknya kestabilan bagi masyarakat keseluruhan, sebab rasa keadilan adalah unsur fitrah kelahiran seseorang sebagai manusia. ${ }^{3}$

Kepastian hukum akan tercapai jika penegakan hukum itu sejalan dengan undang-undang yang berlaku dan rasa keadilan masyarakat yang ditopang oleh kebersamaan tiap individu di depan hukum (equality before the law). Bahwa hukum memandang setiap orang sama, bukan karena kekuasaan dan bukan pula karena kedudukannya lebih tinggi dari yang lain. Persamaan setiap manusia sesuai fitrah kejadiannya:

"Manusia itu adalah umat yang satu, maka Allah mengutus para Nabi sebagai pemberi kabar gembira dan peringatan dan beserta mereka Dia turunkan kitab dengan membawa kebenaran, supaya kitab itu memberi keputusan antara manusia tentang apa yang mereka perselisihkan (QS.2:213).

\section{Penegakan Hukum}

Terdapat beberapa faktor yang dapat mendukung tegaknya hukum di suatu Negara antara lain: Kaidah hukum, Penegak hukum, Fasilitas dan Kesadaran hukum warga Negara. Dalam pelaksanaannya masih tergantung pada sistem politik Negara yang bersangkutan. Jika sistem politik Negara itu otoriter maka sangat tergantung penguasa bagaimana kaidah hukum, penegak hukum dan fasilitas yang ada. Adapun warga Negara ikut saja kehendak penguasa (lihat synopsis). Pada sistem politik demokratis juga tidak semulus yang kita bayangkan. Meski warga Negara berdaulat, jika sistem pemerintahannya masih berat pada eksekutif (Executive heavy) dan birokrasi pemerintahan belum direformasi, birokratnya masih "kegemukan" dan bermental mumpung, maka penegakan hukum masih mengalami kepincangan dan kelambanan (kasus "hotel bintang" di Lapas).

Belum lagi kaidah hukum dalam hal perundang-undangan yang simpang siur penerapannya (kasus Prita). Agar suatu kaidah hukum berfungsi maka bila kaidah itu berlaku secara yuridis, maka kemungkinan besar kaidah tersebut merupakan kaidah mati (dode regel), kalau secara sosiologis (teori kekuasaan), maka kaidah tersebut menjadi aturan pemaksa (dwang maat regel). Jika berlaku secara filosofi, maka kemungkinannya hanya hukum yang dicita-citakan yaitu ius constituendum. ${ }^{4}$ Kaidah hukum atau

\footnotetext{
${ }^{3}$ M. Natsir, 2002: 9

${ }^{4}$ Soerjono Soekanto, 1983.
} 
peraturan itu sendiri, apakah cukup sistematis, cukup sinkron, secara kualitatif dan kuantitatif apakah sudah cukup mengatur bidang kehidupan tertentu. Dalam hal penegakan hukum mungkin sekali para petugas itu menghadapi masalah seperti sejauh mana dia terikat oleh peraturan yang ada, sebatas mana petugas diperkenankan memberi kebijaksanaan. Kemudian teladan macam apa yang diberikan petugas kepada masyarakat. Selain selalu timbul masalah jika peraturannya baik tetapi petugasnya malah kurang baik. Demikian pula jika peraturannya buruk, maka kualitas petugas baik.

Fasilitas merupakan sarana dalam proses penegakan hukum. Jika sarana tidak cukup memadai, maka penegakan hukum pun jauh dari optimal. Mengenai warga negara atau warga masyarakat dalam hal ini tentang derajat kepatuhan kepada peraturan. Indikator berfungsinya hukum adalah kepatuhan warga. Jika derajat kepatuhan rendah, hal itu lebih disebabkan oleh keteladanan dari petugas hukum.

\section{Keadilan}

Pengertian keadilan dapat ditinjau dari dua segi yakni keadilan hukum dan keadilan sosial. Adapun keadilan mengandung asas kesamaan hukum artinya setiap orang harus diperlakukan sama di hadapan hukum. Dengan kata lain hukum harus diterapkan secara adil. Keadilan hukum ternyata sangat erat kaitannya dengan implementasi hukum di tengah masyarakat. Untuk mencapai penerapan dan pelaksanaan hukum secara adil diperlukan kesadaran hukum bagi para penegak hukum.

Dengan demikian guna mencapai keadilan hukum itu, maka faktor manusia sangat penting. Keadilan hukum sangat didambakan oleh siapa saja termasuk penjahat (pembunuh, pemerkosa, dan koruptor). Jika dalam suatu negara ada yang cenderung bertindak tidak adil secara hukum, termasuk hakim, maka pemerintah harus bertindak mencegahnya. Pemerintah harus menegakkan keadilan hukum, bukan malah berlaku zalim terhadap rakyatnya. Keadilan sosial terdapat dalam kehidupan masyarakat, terdapat saling tolong-menolong sesamanya dalam berbuat kebaikan. Terdapat naluri saling ketergantungan satu dengan yang lain dalam kehidupan sosial (interdependensi). Keadilan sosial itu diwujudkan dalam bentuk upah yang seimbang, untuk mencegah diskriminasi ekonomi. Keadilan sosial adalah persamaan kemanusiaan, suatu penyesuaian semua nilai, nilai-nilai yang termasuk dalam pengertian keadilan. Kepemilikan atas harta seharusnya 


\section{Rais Ahmad}

tidak bersifat mutlak. Perlu dilakukan pemerataan, distribusi kekayaan anggota masyarakat. Bagaimana pemilik harta seharusnya menggunakan hartanya. Penimbunan atau konsentrasi kekayaan, sehingga tidak dimanfaatkan dalam sirkulasi dan distribusi akan merugikan kepentingan umum. Sebaiknya harta kekayaan itu digunakan sebaik mungkin dan memberikan manfaat bagi pemiliknya maupun bagi masyarakat.

\section{Hukum dan Keadilan Dalam Islam}

Menurut M. Natsir (demokrasi dibawah hukum cet.III, 2002) adalah suatu penegasan, ada undang-undang yang disebut Sunnatullah yang nyatanyata berlaku dalam kehidupan manusia pada umumnya. Perikehidupan manusia hanya dapat berkembang maju dalam berjama'ah (Society).

Man is born as a social being. Hidup perorangan dan hidup bermasyarakat berjalin, yang satu bergantung pada yang lain. Kita mahluk sosial harus berhadapan dengan berbagai macam persoalan hidup, dari persoalan rumah tangga, hidup bermasyarakat, berbangsa, bernegara, berantara negara, berantar agama dan sebagainya, semuanya problematika hidup duniawi yang bidangnya amat luas. Maka risalah Muhammad Saw, meletakkan beberapa kaidah yang memberi ketentuan-ketentuan pokok guna memecahkan persoalan-persoalan.

Kestabilan Hidup bermasyarakat memerlukan tegaknya keadilan lanjut M. Natsir. Tiap-tiap sesuatu yang melukai rasa keadilan terhadap sebagian masyarakat, maka bisa merusak kestabilan secara keseluruhan. Menegakkan keadilan di tengah-tengah masyarakat dan bangsa diawali dengan kedaulatan hukum yang ditegakkan. Semua anggota masyarakat berkedudukan sama di hadapan hukum. Jadi di hadapan hukum semuanya sama, mulai dari masyarakat yang paling lemah sampai pimpinan tertinggi dalam Negara.

“Dan janganlah rasa benci kamu kepada suatu golongan menyebabkan kamu tidak berlaku adil. Berlaku adilah, karena itu lebih dekat kepada taqwa. Dan bertaqwalah kepada Allah karena sesungguhnya Allah amat mengetahui apa yang kamu kerjakan"(QS.5:8).

"Dengarlah dan taatilah sekalipun andaikata yang menjalankan hukum atasmu seseorang budak Habsyi yang kepalanya seperti kismis selama dijalankannya hukum Allah Swt". (H.R.Buchori dari Anas) 
Tidak mungkin hukum dan keadilan dapat tegak berdiri keadilan dapat tegak berdiri kokoh apabila konsep persamaan itu diabaikan. Implementasi keadilan hukum di masyarakat dewasa ini banyak ditemui sandungan yang menyolok atas pandangan lebih terhadap orang yang punya kedudukan tinggi, yang punya kekayaan melimpah, sehingga rakyat banyak telah menyimpan imej bertahun-tahun bahwa di negeri ini keadilan itu dapat dibeli. Lebih jauh kesamaan itu dijabarkan Rachman di bukunya Political Science and Government dalam Ramly Hutabarat di bukunya Hukum dan Demokrasi (1999) yaitu, yakni:

a. Manusia secara alamiah dilahirkan sama (Natural Equality)

b. Setiap masyarakat memiliki kesamaan hak sipil

c. Semua warga negara memiliki hak yang sama mendapatkan lapangan pekerjaan

d. Semua warga Negara sama kedudukannya dalam politik.

QS.4:135."Wahai orang-orang yang beriman jadilah kamu orang yang tegak menegakkan keadilan, menjadi saksi kebenaran karena Allah, biarpun terhadap dirimu sendiri atau ibu bapakmu atau kerabatmu".

\section{Penutup}

Seorang raja dan hati pemuda dalam synopsis di awal tulisan ini tak akan ada lagi dalam alam demokrasi sekarang ini. Namun bisa lebih dari hanya sekedar pembunuhan fisik, malah sering terjadi pembunuhan karakter dan pengorbanan hati nurani yang paling dalam. Mudah-mudahan jika bangsa ini mulai berpaling kepada ajaran Islam yang sempurna, insyaAllah tegaknya hukum dan keadilan itu suatu keniscayaan.

\section{Pustaka Acuan}

Hamzah, Andi Penegakan Hukum Lingkungan, Sinar Grafika, 2005.

Natsir,M Demokrasi dibawah Hukum, Media Dakwah, Jakarta Cet.III 2002.

Hutabarat, Ramly Hukum dan Demokrasi menurut M.Natsir, Biro Riset DDII Jakarta, 1999.

Soekamto, Soeryono, Faktor-faktor yang Mempengaruhi Penegakan Hukum, Radja Gravindo Persada, Jakarta 1993 penegakan Hukum, BPHN DEPKES, 1983

Natsir, Chaidar, Republika Minggu, 7 Maret 2010 